\title{
PENGARUH LINGKUNGAN KERJA TERHADAP KINERJA YANG DIMEDIASI OLEH MOTIVASI KERJA KARYAWAN ROCKY PLAZA HOTEL PADANG
}

\author{
Fiska Permata Sari, Nazaruddin Aziz \\ Sekolah Tinggi Ilmu Ekonomi "KBP" \\ nazaruddinaziz@akbpstie.ac.id
}

\begin{abstract}
ABSTRAK
Penelitian ini bertujuan untuk mengetahui pengaruh dari lingkungan kerja terhadap kinerja karyawan yang dimediasi oleh motivasi kerja. Penentuan sampel dilakukan dengan cara random sampling yaitu teknik pengambilan sampel secara acak sederhana. Jumlah sampel yang digunakan dalam penelitian ini sebanyak 55 karyawan. Dalam penelitian ini, ketiga variabel tersebut dianalisis menggunakan analisis regresi linear sederhana melalui uji signifikansi dengan program SPSS. Objek penelitian ini adalah sebagian karyawan Rocky Plaza Hotel padang. Hasil penelitian ini menunjukkan bahwa lingkungan kerja berpengaruh terhadap kinerja karyawan Rocky Plaza Hotel Padang, dengan demikian hipotesis 1 didukung. Lingkungan kerja berpengaruh terhadap motivasi kerja karyawan Rocky Plaza Hotel Padang, dengan demikian hipotesis 2 didukung. Adapula motivasi kerja berpengaruh terhadap kinerja karyawan Rocky Plaza Hotel Padang, dengan demikian hipotesis 3 didukung. Selain itu, hasil penelitian menunjukkan bahwa lingkungan kerja berpengaruh terhadap kinerja yang dimediasi oleh motivasi kerja karyawan Roacky Plaza Hotel Padang, dengan demikian hipotesis 4 didukung.
\end{abstract}

Kata Kunci : lingkungan kerja, motivasi kerja, kinerja karyawan

\section{PENDAHULUAN}

Sumber daya manusia merupakan salah satu unsur dari organisasi dan mempunyai peranan yang penting dalam kegiatan organisasi. Notoatmodjo (2003) mengemukakan bahwa manusia sebagai salah satu komponen organisasi merupakan sumber daya penentu tercapainya visi dan misi organisasi. Oleh sebab itu sumber daya manusia harus dikelola sedemikian rupa sehingga berdaya guna dan berhasil guna dalam mencapai misi dan tujuan organisasi. Organisasi merupakan suatu sistem, yaitu rangkaian dan hubungan antar bagian komponen yang bekerja sama secara keseluruhan. Dimana setiap komponen merupakan sub sistem yang memiliki kekayaan sistem bagi dirinya. Terdapat hubungan yang erat antara kinerja perorangan dengan kinerja organisasi. Dengan kata lain bila kinerja karyawan baik maka 
kemungkinan besar kinerja organisasi juga baik. Oleh karena itu oganisasi harus benar-benar memperhatikan faktor sumber daya manusianya. Hal yang penting dalam pengelolaan sumber daya manusia adalah mengenai kinerja pegawai. Kinerja pegawai menurut Mangkunegara (2003) adalah sebagai hasil kerja secara kualitas dan kuantitas yang dapat dicapai oleh seorang karyawan dalam melaksanakan tugas sesuai dengan tanggung jawab yang diberikan kepadanya. Agar kinerja karyawan selalu konsisten maka setidak-tidaknya organisasi selalu memperhatikan lingkungan kerja, dan motivasi kerja.

Dalam kondisi saat ini, perubahan lingkungan bisnis, baik teknologi, politik, ekonomi sangat berpengaruh pada perusahaan-perusahaan besar khususnya dalam menhadapi persaingan. Pada umumnya perusahaan yang tidak mampu menghadapi persaingan memiliki kinerja dan kualitas produk yang rendah. untuk mampu membawa organisasi perusahaan dalam memasuki lingkungan bisnis, manajer harus bertanggung jawab untuk merencanakan dan memiliki kompetensi untuk melakukan perubahan sesuai dengan yang diharapkan. Kesuksesan suatu organisasi dalam mengelola sumber daya manusia yang dimiliki sangat menentukan keberhasilan pencapaian tujuan organisasi.

Simamora $(2002 ; 21)$ Kinerja merupakan hasil kerja yang dapat dicapai oleh seseorang atau sekelompok orang dalam suatu organisasi sesuai dengan wewenang dan tanggung jawab masing-masing, dalam rangka upaya mencapai tujuan organisasi bersangkutan secara legal, tidak melanggar hukum dan sesuai dengan moral maupun etika. Tiffin dan Mc. Cormick ( dalam As'ad, 2001; 49) kinerja dipengaruhi oleh banyak fakor diantaranya faktor individual dan faktor situasional. Faktor individual meliputi sikap, sifat-sifat kepribadian, sifat fisik, keinginan atau motivasinya, umur, jenis kelamin, tingkat pendidikan, latar belakang budaya, dan variabel-variabel personal lainnya. Sedangkan faktor situasional meliputi faktor sosial dan organisasi, faktor fisik dan pekerjaan. Faktor sosial dan organisasi meliputi kebijakan organisasi, jenis latian dan pengawasan, sistem upah dan lingkungan sosial. Faktor fisik dan pekerjaan, meliputi : metode kerja, desain dan kondisi alat-alat kerja, penentuan ruang kerja dan lingkungan kerja.

Dalam penelitian ini peneliti meneliti tentang lingkungan kerja dan motivasi kerja. Jika lingkungan kerja dan motivasi kerja baik maka kinerja yang dihasilkan juga akan baik. Lingkungan kerja dapat menciptakan hubungan kerja yang mengikat antara orang-orang yang ada didalam lingkungannya. Oleh karena itu, hendaknya diusahakan agar lingkungan kerja harus baik dan kondusif karena lingkungan kerja yang baik dan kondusif menjadikan karyawan merasa betah berada diruangan dan merasa sengan serta bersemangat untuk melaksanakan tugas-tugasnya sehingga kepuasan kerja akan terbentuk dan dari kepuasan karyawan tersbut maka kinerja karyawan karyawan juga akan meningkat.

Motivasi merupakan faktor yang sangat menentukan kinerja (Griffin 2003; 301). Motivasi merupakan dorongan, keinginan, hasrat dan tenaga penggerak yang berasal dari diri manusia untuk berbuat atau untuk melakukan sesuatu (Wursanto, 2005; 301). Jadi pada dasarnya apabila perusahaan ingin meraih kinerja yang optimal sesuai dengan target yang telah di tentukan maka perusahaan haruslah memberikan motivasi pada karyawan agar karyawan mau dan rela mencurahkan tenaga dan 
pikiran yang dimiliki demi pekerjaan. Persoalan dalam memotivasi karyawan tidak mudah karna dalam diri karyawan terdapat keinginan, kebutuhan dan harapan yang berbeda antara satu karyawan dengan karyawan lain. Jadi apabila manajemen dapat memahami persoalan motivasi dan mengatasinya makan perusahaan akan mendapatkan kinerja karyawan yang optimal sesuai dengan standar yang ditentukan. Pada dasarnya sudah ada lingkungan kerja dan motivasi yang baik pada Rocky Plaza Hotel Padang, akan tetapi masih ditemukan adanya persentasi yang fluktuatif. Dalam hal ini masih banyak karyawan yang datang terlambat masuk kerja dan tidak masuk kerja tanpa adanya surat keterangan.

Rocky Plaza Hotel Padang yang beralokasi dijalan Permindo No. 40, Sumatera Barat 25000. Jika dilihat dari kinerja karyawan Rocky Plaza Hotel Padang, masih dikatakan kurang baik, hal ini dapat dilihat dari data absensi karyawan. Berikut adalah data absensi karyawan Rocky Plaza Hotel Padang dari bulan Juli tahun 2015 sampai dengan bulan Juli tahun 2016, rata-rata absensi sebanyak 16 karyawan dengn persentasi absensi $14 \%$.

Dapat dilihat bahwa jumlah absensi karyawan di Rocky Plaza Hotel Padang masih dirasa terlalu banyak, terdapat beberapa karyawan yang tidak masuk kerja tanpa keterangan dan ada juga yang cuti kerja. Terdapat fluktuasi kenaikan dan penurunan persentase absensi dibulan tertentu, (Juli, Agustus, September, Oktober, November, Desember, Januari, Februari, Maret, April, dan Mei) persentasi absensi diatas 10 Persen yang menunjukan bahwa tingkat absensi yang cukup tinggi dan belum lagi masih ditambah dengan karyawan yang terlambat bekerja. Dari data tersebut diatas dapat dilihat bahwa rata-rata absensi karyawan adalah sebanyak 16 karyawan atau 14 persen setiap bulan. Hal ini apabila di biarkan terus menerus nantinya akan memberika permasalahan yang serius bagi organisasi secara keseluruhan.

Dalam indikator kinerja karyawan menurut Desler kehadiran merupakan salah satu point yang mencerminkan kinerja karyawan. Padahal karyawan telah di motivasi dengan berbagai hal seperti: pemberian gaji dan tunjangan yang di sesuaikan dengan pekerjaan, adanya jaminan kesehatan, adanya diklat untuk menambah dan meningkatkan ketrampilan SDM para karyawan dan lain-lain. Adapun lingkungan kerja Rocky Plaza Hotel Padang peneliti mengetahui dari observasi awal, dalam kondisi keamanan perusahaan sangat memberikan perhatian khusus dengan adanya pemeriksaan kepada setiap tamu yang datang.

Berdasarkan permasalahan tersebut diatas, maka penulis mencoba mengangkatnya kedalam penulisan skripsi dengan judul "Pengaruh Lingkungan Kerja Terhadap Kinerja Yang Dimediasi Oleh Motivasi Kerja Karyawan Pada Rocky Plaza Hotel Padang"

Rumusan Masalah

Berdasarkan latar belakang diatas, maka permasalahan yang akan dikaji dalam penelitian ini adalah:

1. Bagaimana pengaruh Lingkungan Kerja terhadap Kinerja karyawan Rocky Plaza Hotel Padang?

2. Bagaimana pengaruh Lingkungan Kerja terhadap Motivasi Kerja karyawan Rocky Plaza Hotel Padang? 
3. Bagaimana Pengaruh Motivasi Kerja terhadap Kinerja karyawan Rocky Plaza Hotel Padang?

4. Bagaimana Pengaruh Lingkungan Kerja terhadap Kinerja apabila di mediasi oleh Motivasi Kerja karyawan pada Rocky Plaza Hotel Padang?

Tujuan Penelitian

1. Untuk menguji pengaruh Lingkungan Kerja terhadap Kinerja karyawan Rocky Plaza Hotel Padang.

2. Untuk menguji pengaruh Lingkungan Kerja terhadap Motivasi Kerja karyawan Rocky Plaza Hotel Padang.

3. Untuk menguji Pengaruh Motivasi Kerja terhadap Kinerja karyawan Rocky Plaza Hotel Padang.

4. Untuk menguji Pengaruh Lingkungan Kerja terhadap Kinerja apabila di mediasi oleh Motivasi Kerja karyawan pada Rocky Plaza Hotel Padang.

\section{LANDASAN TEORI}

Manajemen sumber daya manusia merupakan rangkaian aktivitas organisasi yang diarahkan untuk menarik, mengembangkan, dan mempertahankan tenaga kerja yang efektif. Manajemen sumber daya manusia diperlukan dalam konteks lingkungan yang kompleks dan terus berubah. Menurut Hasibuan (1994:11) bahwa sumber daya manusia menyelenggarakan kepemimpinan dan pengarahan karyawan dalam pekerjaan atau hubungan kerja diantara mereka.

\section{Lingkungan Kerja}

Lingkungan kerja adalah sesuatu yang ada disekitar para pekerja dan dapat mempengaruhi dirinya dalam menjalankan tugas yang dibebankannya. Instansi harus dapat memperhatikan kondisi yang ada dalam perusahaan baik didalam maupun diluar ruangan tempat kerja, sehingga karyawan dapat bekerja dengan lancar dan merasa aman. Kondisi lingkungan kerja dikatakan baik atau sesuai apabila manusia dapat melaksanakan kegiatan secara optimal, sehat, aman, dan nyaman (Nursasongko, 2012). Menurut Supardi (2003) lingkungan kerja merupakan keadaan sekitar tempat kerja baik secara fisik maupun non fisik yang dapat memberikan kesan menyenangkan, mengamankan, menentramkan dan kesan betah bekerja dan lain sebagainya. Sedangkan menurut Dale (2002) lingkungan kerja yang menyenangkan mungkin menjadi pendorong bagi karyawan untuk menghasilkan kinerja puncak.

\section{Arti Penting Lingkungan Kerja}

Semangat dan kegairahan kerja karyawan dalam menjalankan tugas - tugas yang dibebankan dipengaruhi banyak faktor. Salah satu faktor tersebut adalah lingkungan kerja. Faktor ini penting dan besar pemgaruhnya, namun banyak perusahaan maupun instansi - instansi lainnya yang kurang memperhatikan faktor ini. Dengan demikian dapat dimengeri bahwa lingkungan kerja juga dapat mempengaruhi tingkat kenerja karyawan.

\section{Motivasi Kerja}

Motivasi berasal dari kata Motivation, yang artinya dorongan daya batin, sedangkan to motivate artinya mendorong untuk berprilaku atau berusaha. Motivasi dalam manajemen, lebih menitikberatkan pada bagaimana caranya mengarahkan daya 
dan pontensi bawahan, agar mau bekerja sama secara produktif berhasil mencapai dan mewujudkan tujuan yang telah ditentukan.

Motivasi adalah dorongan karyawan atau sikap mental karyawan yang mengarah atau mendorong perilaku kearah pencapaian kebutuhan yang memberikan kepuasan (Hasibuan, 2003). Sedangkan menurut Robbins (2006) bahwa motivasi merupakan proses yang menjelaskan intensitas, arah dan ketekunan seseorang individu untuk mencapai tujuan. Tiga elemen utama dalam definisi tersebut adalah intensitas berhubungan dengan seberapa giat seseorang berusaha, arah merupakan tujuan sedangkan ketekunan merupakan ukuran mengenai berapa lama seseorang bisa mempertahankan usahanya.

\section{Indikator Motivasi}

a) Kebutuhan akan prestasi

1. Memiliki kesempatan untuk berprestasi

2. Kesempatan untuk mengikuti pendidikan dan pelatihan

3. Bangga hasil kerja menjadi acuan bagi teman sejawat

b) Kebutuhan akan kekuasaan

1. Memiliki kewenangan dan tanggung jawabterhadap keberhasilan perusahaan

2. Mempunyai wewenang untuk menyelesaikan pekerjaan dengan metode sendiri

3. Mendapatkan kedudukan yang lebih baik dengan cara bersaing secara sehat

c) Kebutuhan akan afiliasi

1. Menjalin hubungan dengan sesama pegawai dan atasan.

2. Memiliki kesempatan membantu teman sejawat

3. Mendapat pengakuan dari masyarakat atas pekerjaannya

\section{Kinerja Karyawan}

Menurut Rivai (2008) kinerja merupakan perilaku nyata yang ditampilkan setiap orang sebagai prestasi kerja yang dihasilkan oleh karyawan sesuai dengan perannya dalam perusahaan. Kinerja merupakan suatu hal yang sangat penting dalam upaya perusahaan untuk mencapai tujuannya. Simamora (2006) menyatakan kinerja mengacu kepada kadar pencapaian tugas-tugas yang membentuk sebuah pekerjaan karyawan. kinerja merefleksikan seberapa baik karyawan memenuhi persyaratan sebuah pekerjaan.

\section{Pengukuran Kinerja}

Pengukuran kinerja (performance appraisal) pada dasarnya merupakan tolok ukur efisiensi sumber daya yang tersedia dalam perusahaan. Walaupun kinerja hanyalah merupakan rasio atau perbandingan namun demikian manfaat kinerja pegawai cukup besar pengaruhnya bagi negara pada umumnya dan perusahaan pada khususnya. Menurut Narmodo dan Wajdi (2009) ada 5 (lima) faktor dalam penilaian kinerja, yaitu :

1. Kualitas pekerjaan meliputi; akuisisi, ketelitian, penampilan dan penerimaan keluaran.

2. Kuantitas pekerjaan meliputi; volume keluaran dan kontribusi

3. Supervisi meliputi; membutuhkan saran, arahan/ perbaikan.

4. Kehadiran meliputi; regularitas, dapat dipercaya/diandalkan dan ketepatan waktu.

5. Konservasi meliputi; pencegahan, pemborosan, kerusakan dan pemeliharaan. 


\section{Penelitian Terdahulu}

Pada Penelitian Emilia Noviani Asta Sari berjudul Pengaruh Lingkungan Kerja Terhadap Kinerja Karyawan Bagian p;roduksi PT. Glory Industrial Semarang II (2009). Hasil penelitiaan menunjukkan bahwa Didalam penelitian tersebut ada pengaruh positif antara lingkungan kerja terhadap kinerja karyawan bagian produksi PT. Glory Industrial Semarang II dengan Koefisien Parsial sebesar 18,49\%. Pada Penelitian Linda Firnindia berjudul Pengaruh Motivasi Terhadap Kinerja Pegawai Dinas Pendidikan dan Kebudayaan Kabupaten Jepara. (2008) Hasil penelitiaan menunjukkan bahwa Didalam penelitian tersebut ada pengaruh positif antara Motivasi terhadap Kinerja pada pegawai Dinas Pendidikan dan Kebudayaan Kabupaten Jepara dengan Koefisien Parsial sebesar 31,3\%.

\section{METODE PENELITIAN \\ Jenis Penelitian}

Jenis penelitian yang dilakukan dalam penelitian ini adalah penelitian survei, menurut Abdurahman (2011 : 16) penelitian survei adalah penelitian yang dilakukan terhadap sejumlah individu atau unit analisis, sehingga ditemukan fakta atau keterangan secara faktual mengenai gejala suatu kelompok atau perilaku individu dan hasilnya dapat digunakan sebagai bahan pembuatan rencana atau pengambilan keputusan. Penelitian survei ini merupakan studi yang bersifat kuantitatif dan umumnya survei menggunakan kuesioner sebagai alat pengumpulan datanya.

\section{Populasi}

Populasi menurut Sutrisno Hadi (2001) adalah sekumpulan dari seluruh elemen-elemen yang dalam hal ini diatrikan sebagai objek penelitian. Adapun populasi dalam penelitian ini adalah karyawan Rocky Plaza Hotel 122 karyawan.

\section{Sampel}

Dengan jumlah populasi yang diketahui, maka pengambilan jumlah sampel penelitian dihitung dengan menggunakan rumus Slovin (Umar 2008:78), yaitu :

Dimana:

$$
n=\frac{N}{1+N e^{2}}
$$

$n=$ Jumlah sampel

$\mathrm{N}=$ Jumlah populasi

$\mathrm{e}=$ Persen tingkat kesalahan yang dapat ditolerir dalam penelitian ini, $\mathrm{N}=122$ dan $\mathrm{e}=10 \%$

$$
\begin{aligned}
\mathrm{n} & =\frac{122}{1+122(10 \%)^{2}} \\
& =\frac{122}{1+122(0.1)^{2}} \\
& =\frac{122}{2.22} \\
& =54,95 \text { Pembulatan } 55 \text { orang responden. }
\end{aligned}
$$

\section{Jenis dan Sumber Data}

Dalam penelitian ini menggunakan data antara lain : 


\section{Data Primer}

Data Primer merupakan data yang bersumber dari tangan pertama, data yang diambil menggunakan cara kuesioner. Kuisioner merupakan daftar pertanyaan yang dipakai sebagai pedoman untuk mengadakan tanya jawab dengan responden mengenai pengaruh lingkungan kerja, motivasi kinerja terhadap kinerja karyawan.

2. Data Sekunder

Data Sekunder adalah jenis data yang diperoleh dan digali melalui hasil pengelolahan pihak kedua dari hasil penelitian lapangannya, baik berupa data kuantitatif dan kualitatif (Sutrisno Hadi, 2001). Data ini disebut juga data eksternal.

\section{Teknik Pengumpulan Data}

Untuk mengumpulkan data yang diperlukan dalam penelitian ini digunakan beberapa teknik yaitu :

1. Pengisian angket/wawancara terstruktur dengan menggunakan kuesioner dan pedoman wawancara untuk mendapatkan informasi yang mendalam tentang lingkungan kerja, motivasi kerja dan kinerja karyawan, budaya organisasi dan kinerja.

2. Teknik pengamatan atau observasi dilakukan dilokasi penelitian dengan mengamati wawasan, sikap dan perilaku sasaran untuk memperoleh gambaran yang lebih lengkap dan mendalam tentang masalah yang diteliti.

\section{Definisi Operasional}

Untuk memberikan kejelasan mengenai variabel penelitian yang digunakan berikut dirumuskan definisi operasional masing-masing variabel :

\section{Lingkungan Kerja (X)}

Lingkungan kerja adalah segala sesuatu yang ada disekitar para pekerja yang dapat mempengaruhi dirinya dalam menjalan tugas yang dibebankan (Nitisemito, 2002).

\section{Motivasi Kerja (M)}

Motivasi kerja adalah proses yang menjelaskan intensitas, arah dan ketekunan seorang individu untuk mencapai tujuan (Robbins, 2006)

\section{Kinerja Karyawan (Y)}

Kinerja karyawan sebagai hasil kerja secara kualitas dan kuantitas yang dapat dicapai oleh seseorang karyawan dalam melaksanakan tugas sesuai dengan tanggung jawab yang diberikan kepadanya (Mangkunegara, 2003).

\section{Uji Validitas}

Pernyataan dinyatakan valid jika corrected item-total correlation $>0,36$ (Idris, 2010 : 11). Uji validitas ini dilakukan melalui program SPSS (Statistical Product Service Solution) versi 17.0.

\section{Uji Realibilitas}

Instrumen dinyatakan reliabel jika alpha cronbach > 0,60 (Idris 2010:8). Pengujian realiabilitas instrument dihitung menggunakan program SPSS versi 17.0.

\section{Teknik Analisa Data}

Analisis data yang digunakan dalam penelitian ini adalah analisis kuantitatif dengan menggunakan SPSS 17.0.

\section{Analisis Deskriptif}


Menurut Bungin (2005 : 181) analisis deskriptif merupakan penelititan kuantitatif yang berrtujuan untuk mendeskripsikan keadaan gejala sosial yang tampak dan melihat hubungan kausalitas antara gejala-gejala tersebut. Setelah data terkumpul kemudian disajikan ke dalam tabel distribusi frekuensi untuk dilakukan analisis deskriptif. Analisis ini digunakan untuk melihat gambaran secara umum tentang variabel yang diteliti dengan analisis persentase.

Pengkategorian niai pencapaian responden digunakan klasifikasi menurut Riduan (2006 : 89):

Tabel 1

Rentang Skala TCR

\begin{tabular}{|c|c|c|}
\hline No & Rentang Skala & TCR \\
\hline 1 & $81-100 \%$ & Sangat baik \\
\hline 2 & $61-80 \%$ & Baik \\
\hline 3 & $41-60 \%$ & Sedang \\
\hline 4 & $21-40 \%$ & Kurang \\
\hline 5 & $0-20 \%$ & Sangat baik \\
\hline
\end{tabular}

Untuk mendapatkan rata-rata skor masing-masing indikator dalam pernyataan-pernyataan yang terdapat dalam kuesioner yaitu:

$$
\begin{aligned}
& \mathrm{SS}=\text { Sangat Setuju } \\
& \mathrm{S}=\text { Setuju } \\
& \mathrm{KR}=\text { Kurang Setuju } \\
& \mathrm{TS}=\text { Tidak setuju } \\
& \text { STS = Sangat Tidak setuju }
\end{aligned}
$$

\section{Uji Asumsi Klasik}

\section{Uji Normalitas}

Jika data menyebar disekitar garis diagonal dan mengikuti arah garis diagonal atau grafik histogramnya menunjukkan distribusi normal, maka model regresi memenuhi asumsi normalitas.

Jika data menyebar jauh dari diagonal dan atau tidak mengikuti arah garis diagonal atau grafik histogram tidak menunjukkan distribusi normal, maka model regresi tidak memenuhi asumsi normalitas.

\section{Uji Heteroskedastisitas}

Kriteria pengambilan keputusan adalah jika tidak ada pola yang jelas, serta titik-titik menyebar di atas dan di bawah angka 0 pada sumbu Y, maka tidak terjadi heteroskedastisitas.

\section{Analisis Regresi Sederhana}

Model statistik yang digunakan dalam penelitian ini dirancang untuk meneliti pengaruh dari variabel bebas terhadap variabel terikat. Adapun rumusan model Regresi Linear Sederhana tersebut adalah:

$$
\mathrm{Y}=\alpha+\beta \mathrm{x}
$$

Dimana :

$\mathrm{Y}=$ Variabel Terikat (dependent)

$\mathrm{X}=$ Variable Bebas (idependent) 
$\alpha=$ Nilai Konstanta

$\beta=$ Nilai Koefisien Regresi

\section{Uji Hipotesis}

Uji t

Dalam penelitian ini peneliti akan melakukan pengolahan data dengan bantuan program SPSS 17.0. Kriteria pengambilan keputusannya adalah sebagai berikut;

1. Jika signifikan $\leq \alpha$ maka keputusannya adalah Ho ditolak dan Ha diterima.

2. Jika signifikan $\geq \alpha$ maka keputusannya adalah Ho diterima dan Ha ditolak. Uji F

Uji $\mathrm{F}$ adalah untuk menguji adanya pengaruh variabel independen secara serempak terhadap variabel dependen.Aturan penolakan dan penerimaan uji $\mathrm{F}$, di mana kita akan menerima $\mathrm{H}_{0}$ jika $\mathrm{F}$ hitung lebih kecil dari $\mathrm{F}$ tabel dan menolak $\mathrm{H}_{0}$ jika F hitung lebih besar dari F tabel. Menurut Abdurahman (2011 : 230) rumus mencari F hitung:

Pengujian dapat dilakukan dengan membandingkan nilai Sig dengan $\alpha$ dengan kriteria sebagai berikut:

1. Jika Sig $\leq \alpha$ akibatnya Ho ditolak dan Ha diterima

2. Jika Sig $\geq \alpha$ akibatnya Ho diterima dan Ha ditolak.

\section{HASIL PENELITIAN DAN PEMBAHASAN} Analisis Regresi Linear Sederhana

Analisis Regresi linear sederhana adalah regresi yang memiliki satu variabel dependen dan satu variabel independen (Nugroho dalam Aisyah, 2007). Model persamaan yang dapat digambarkan adalah sebagai berikut :

\section{Tabel 2}

\section{Uji Analisis Regresi Linear Sederhana}

\begin{tabular}{|c|c|c|c|c|c|}
\hline \multicolumn{6}{|c|}{ Coefficients $^{a}$} \\
\hline \multirow[b]{2}{*}{ Model } & \multicolumn{2}{|c|}{ Unstandardized Coefficients } & $\begin{array}{l}\text { Standardized } \\
\text { Coefficients }\end{array}$ & & \\
\hline & $\mathrm{B}$ & Std. Error & Beta & $\mathrm{t}$ & Sig. \\
\hline $1 \quad$ (Constant) & 12.755 & 5.551 & & 2.298 & .026 \\
\hline$x$ & .434 & .079 & .602 & 5.488 & .000 \\
\hline
\end{tabular}

a. Dependent Variable: $Y$

Berdasarkan analisis data dengan menggunakan program SPSS 17.0 for Windows, maka diperoleh persamaan regresi sebagai berikut :

$$
\mathrm{Y}=12.755+0.434 \mathrm{x}
$$

Setelah diperoleh garis regresi, langkah selanjutnya adalah menguji hipotesis dan dianalisis, sehingga didapatkan jawabannya. Ho dapat diterima apabila $\beta=0$ dan Ho ditolak apabila $\beta>0$. Hasil perhitungan dari SPSS Nampak bahwa $\beta$ $(0,434)>0$, maka $\mathrm{H} 1$ diterima dan Ho ditolak sehingga lingkungan kerja berpengaruh signifikan terhadap kinerja kerja karyawan. Nilai konstanta sebesar $(\alpha)=12.755$ dan bersifat positif yang berarti bahwa apabila $\mathrm{X}$ tidak dapat memberikan kontribusi $(\mathrm{X}=0)$ terhadap $\mathrm{Y}$, maka nilai $\mathrm{Y}=12.755$. Titik potong garis regresi sederhana berada di sebelah atas dari titik 0, tepatnya di titik 12.755. Adapun nilai koefisien 
untuk lingkungan kerja bernilai positif sebesar 0,434 yang berarti jika nilai lingkungan kerja meningkat 1 poin, maka nilai kinerja karyawan juga akan meningkat 1 poin sebesar 0,434 .

Diketahui nilai koefisien korelasi (R) sebesar 0.602. Hal tersebut menunjukkan seberapa besar hubungan antara variabel dependen dalam hal ini ligkungan kerja dengan variabel independen kinerja karyawan. Nilai R sebesar 0,602 menunjukkan bahwa variabel lingkungan kerja mempunyai pengaruh terhadap kinerja sebesar 60,2\% sedangkan sisanya dipengaruhi oleh variabel yang lain.

\section{Uji Hipotesis}

Uji t

Hipotesis dalam penelitian ini adalah lingkungan kerja berpengaruh positif dan signifikan terhadap kepuasan nasabah. Berdasarkan Tabel 4.19 diketahui bahwa nilai koefisien dari lingkungan kerja bernilai positif 0,434 dan nilai t hitung adalah sebesar 5.488 dengan signifikan $0,000<0,05$. Hal ini berarti lingkungan kerja berpengaruh positif dan signifikan terhadap kinerja. Sehingga dapat dikatakan bahwa hipotesis dapat diterima.

\section{Uji F}

Dari uji ANOVA atau F test di dapat nilai $F$ hitung sebesar 30.123 dengan tingkat signifikasi 0.000 . karena probabilitas signifikan jauh lebih kecil dari 0.05 maka Ho di tolak dan Ha diterima. Karena tingkat signifikansi 0,000 $<0,05$ maka model regresi dapat digunakan untuk memprediksi kinerja karyawan (Y) atau dikatakan bahwa variabel lingkungan kerja (X), secara bersama-sama atau simultan berpengaruh signifikan terhadap variabel kinerja karyawan (Y).

\section{Hasil Penelitian}

\section{Terdapat Pengaruh Langsung Lingkungan kerja terhadap kinerja}

Hipotesis pertama dalam penelitian ini berbunyi "Terdapat pengaruh langsung lingkungan kerja terhadap kinerja". Pengujian hipotesis untuk membuktikan pengaruh langsung lingkungan kerja terhadap kinerja dengan menggunakan regresi sederhana. Dari hasil analisis regresi dapat diketahui persamaan regresi sebagai berikut:

$$
\mathrm{Y}=12.755+0,434 \mathrm{x}
$$

Persamaan regresi tersebut menunjukkan bahwa nilai koefisien regresi lingkungan kerja (X) sebesar 0,434 yang berarti apabila lingkungan kerja meningkat satu satuan maka kinerja akan meningkat 0,434 satuan.

Hasil statistik uji regresi diperoleh $\mathrm{t}$ hitung sebesar 5.488 dengan nilai signifikansi 0,000, oleh karena nilai signifikansi lebih kecil dari 0,05 $(0,000<0,05)$, dan koefisien regresi mempunyai nilai positif sebesar 0,434 maka hipotesis yang menyatakan bahwa "Terdapat pengaruh langsung lingkungan kerja terhadap kinerja" terbukti. Besarnya pengaruh lingkungan kerja terhadap kinerja sebesar 0,350 hal ini berarti bahwa kinerja dipengaruhi oleh lingkungan kerja sebesar $35,0 \%$, sedangkan sisanya sebesar $65,0 \%$ dipengaruhi oleh faktor lain yang tidak termasuk dalam penelitian ini.

Terdapat Pengaruh Secara Langsung Lingkungan Kerja Terhadap Motivasi Kerja 
Hipotesis kedua dalam penelitian ini berbunyi "Terdapat pengaruh lingkungan kerja terhadap motivasi kerja". Pengujian hipotesis untuk membuktikan pengaruh langsung lingkungan kerja terhadap motivasi kerja dengan menggunakan regresi sederhana.

Dari hasil analisis regresi dapat diketahui persamaan regresi sebagai berikut:

$$
\mathrm{M}=9.076+0,550 \mathrm{x}
$$

Persamaan regresi tersebut menunjukkan bahwa nilai koefisien regresi lingkungan kerja (X) sebesar 0,550 yang berarti apabila lingkungan kerja meningkat satu satuan maka motivasi kerja akan meningkat 0,550 satuan.

Hasil statistik uji regresi diperoleh t hitung sebesar 6.663 dengan nilai signifikansi 0,000 , oleh karena nilai signifikansi lebih kecil dari 0,05 $(0,000<0,05)$, dan koefisien regresi mempunyai nilai positif sebesar 0,550 maka hipotesis yang menyatakan bahwa "Terdapat pengaruh langsung lingkungan kerja terhadap motivasi kerja" terbukti. Besarnya pengaruh lingkungan kerja terhadap motivasi kerja sebesar 0,446 hal ini berarti bahwa motivasi kerja dipengaruhi oleh lingkungan kerja sebesar 44.6\%, sedangkan sisanya sebesar $55.4 \%$ dipengaruhi oleh faktor lain yang tidak termasuk dalam penelitian ini.

\section{Terdapat Pengaruh Langsung Motivasi Kerja Terhadap Kinerja}

Hipotesis ketiga dalam penelitian ini berbunyi "Terdapat pengaruh motivasi kerja terhadap kinerja". Pengujian hipotesis untuk membuktikan pengaruh langsung motivasi kerja terhadap kinerja dengan menggunakan regresi sederhana.

Dari hasil analisis regresi dapat diketahui persamaan regresi sebagai berikut:

$$
\mathrm{Y}=17.152+0,547 \mathrm{M}
$$

Persamaan regresi tersebut menunjukkan bahwa nilai koefisien regresi motivasi kerja (M) sebesar 0,547 yang berarti apabila motivasi kerja meningkat satu satuan maka keputusan pembelian akan meningkat 0,547 satuan.

Hasil statistik uji regresi diperoleh $\mathrm{t}$ hitung sebesar 5.710 dengan nilai signifikansi 0,000, oleh karena nilai signifikansi lebih kecil dari $0,05 \quad(0,000<0,05)$, dan koefisien regresi mempunyai nilai positif sebesar 0,547 maka hipotesis yang menyatakan bahwa "Terdapat pengaruh langsung motivasi kerja terhadap kinerja" terbukti.

Besarnya pengaruh motivasi kerja terhadap keputusan pembelian sebesar 0.369 hal ini berarti bahwa kinerja dipengaruhi oleh motivasi kerja 3,69\%, sedangkan sisanya sebesar $63,1 \%$ dipengaruhi oleh faktor lain yang tidak termasuk dalam penelitian ini.

\section{Pengaruh Lingkungan Kerja terhadap Kinerja melalui Motivasi sebagai Mediasi}

Hipotesis keempat dalam penelitian ini berbunyi "Terdapat Pengaruh Lingkungan Kerja Terhadap Kinerja melalui Motivasi sebagai Mediasi. ". Pengujian hipotesis untuk membuktikan pengaruh langsung motivasi kerja terhadap kinerja dengan menggunakan regresi sederhana.

Dari tabel hasil regresi menunjukkan bahwa nilai koefisien regresi lingkungan kerja terhadap motivasi sebesar 0.343 dengan standar eror 0 , dan nilai signifikansi 
0.001. sehingga lingkungan kerja berpengaruh langsung terhadap motivasi demikian juga motivasi signifikan berpengaruh langsung terhadap kinerja. Nilai M dari Sobel test tidak dapat dihasilkan langsung dari hasil regresi tetapi dengan perhitungan secara manual dengan rumus sobel test. Hasil perhitungan nilai $\mathrm{M}$ dari sobel test adalah:

$$
\begin{aligned}
S a b & =\frac{a b}{\sqrt{\left(b^{2} S E_{a}^{2}\right)+\left(a^{2} S E_{a}^{2}\right)}} \\
S a b & =\frac{0,246 \times 0,343}{\sqrt{\left(0,343^{2} 0,101^{2}\right)+\left(0,246^{2} 0,124^{2}\right)}} \\
S a b & =\frac{0,0843}{\sqrt{0,002129}} \\
S a b & =\frac{0,0843}{0,046141}=1,827
\end{aligned}
$$

Berdasarkan hasil uji Sobel di atas mendapatkan nilai sebesar 1,827, karena nilai yang diperoleh sebesar 1,827 >0,05 maka nilai tersebut membuktikan bahwa motivasi mampu memediasi hubungan pengaruh lingkungan terhadap kinerja.

\section{PEMBAHASAN}

\section{Pengaruh Lingkungan Kerja terhadap Kinerja}

Hasil statistik uji regresi diperoleh $\mathrm{t}$ hitung sebesar 5.488 dengan nilai signifikansi 0,000, oleh karena nilai signifikansi lebih kecil dari 0,05 $(0,000<0,05)$, dan koefisien regresi mempunyai nilai positif sebesar 0,434 maka hipotesis yang menyatakan bahwa "Terdapat pengaruh langsung lingkungan kerja terhadap kinerja" terbukti. Besarnya pengaruh lingkungan kerja terhadap kinerja sebesar 0,350 hal ini berarti bahwa kinerja dipengaruhi oleh lingkungan kerja sebesar $35,0 \%$, sedangkan sisanya sebesar 65,0\% dipengaruhi oleh faktor lain yang tidak termasuk dalam penelitian ini.

Lingkungan kerja adalah sesuatu yang ada disekitar para pekerja dan dapat mempengaruhi dirinya dalam menjalankan tugas yang dibebankannya. Instansi harus dapat memperhatikan kondisi yang ada dalam perusahaan baik didalam maupun diluar ruangan tempat kerja, sehingga karyawan dapat bekerja dengan lancar dan merasa aman. Kondisi lingkungan kerja dikatakan baik atau sesuai apabila manusia dapat melaksanakan kegiatan secara optimal, sehat, aman, dan nyaman (Nursasongko, 2012).

Hasil penelitian ini mendukung penelitian yang dilakukan oleh Emilia Noviani Asta Sari (2009) melakukan penelitian tentang "Pengaruh Lingkungan Kerja Terhadap Kinerja Karyawan Bagian p;roduksi PT. Glory Industrial Semarang II" Hasil penelitian tersebut menunjukkan bahwa ada pengaruh positif antara lingkungan kerja terhadap kinerja karyawan dengan Koefisien Parsial sebesar 18,49\%.

\section{Pengaruh Lingkungan Kerja Terhadap Motivasi Kerja}

Hasil statistik uji regresi diperoleh t hitung sebesar 6.663 dengan nilai signifikansi 0,000, oleh karena nilai signifikansi lebih kecil dari 0,05 $(0,000<0,05)$, dan koefisien regresi mempunyai nilai positif sebesar 0,550 maka hipotesis yang menyatakan bahwa "Terdapat pengaruh langsung lingkungan 
kerja terhadap motivasi kerja" terbukti. Besarnya pengaruh motivasi kerja terhadap keputusan pembelian sebesar 0.369 hal ini berarti bahwa kinerja dipengaruhi oleh motivasi kerja 3,69\%, sedangkan sisanya sebesar $63,1 \%$ dipengaruhi oleh faktor lain yang tidak termasuk dalam penelitian ini.

Menurut Arep dan Tanjung (2003), Motivasi adalah sesuatu yang mendorong seseorang untuk bekerja. Dengan demikian dapatdikatakan bahwa motivasi merupakan kekuatan yang digunakan untuk mencapai suatu tujuan. Motivasi merupakan dorongan, keinginan, hasrat dan tenaga penggerak yang berasal dari diri manusia untuk berbuat atau untuk melakukan sesuatu (Wursanto, 2005; 301). Jadi pada dasarnya apabila perusahaan ingin meraih kinerja yang optimal sesuai dengan target yang telah di tentukan maka perusahaan haruslah memberikan motivasi pada karyawan agar karyawan mau dan rela mencurahkan tenaga dan pikiran yang dimiliki demi pekerjaan. Persoalan dalam memotivasi karyawan tidak mudah karna dalam diri karyawan terdapat keinginan, kebutuhan dan harapan yang berbeda antara satu karyawan dengan karyawan lain. Jadi apabila manajemen dapat memahami persoalan motivasi dan mengatasinya makan perusahaan akan mendapatkan kinerja karyawan yang optimal sesuai dengan standar yang ditentukan.

Penelitian yang dilakukan Asmirin Noor (2014) dalam penelitiannya bahwa lingkungan kerja berpengaruh positif dan signifikan terhadap motivasi kerja yang terlihat koefisien jalur posif sebesar 0,281 dengan C.R sebesar 4,227 da diperoleh probabilitas signifikan yang disyaratkan sebesar 0,05 . Artinya lingkungan kerja berpengaruh secaa langsung pada motivasi kerj, yang berarti bahwa jika penilaian pegawai terhadap lingkungan kerja semakin baik (meningkat), maka akan meningkatkan motivasi kerja, dan sebaliknya penilaian pegawai terhadap lingkungan kerja semakin menurun, maka akan menurunkan motivasi kerja.

\section{Pengaruh Motivasi Kerja Terhadap Kinerja}

Hasil statistik uji regresi diperoleh $\mathrm{t}$ hitung sebesar 5.710 dengan nilai signifikansi 0,000 , oleh karena nilai signifikansi lebih kecil dari 0,05 $(0,000<0,05)$, dan koefisien regresi mempunyai nilai positif sebesar 0,547 maka hipotesis yang menyatakan bahwa "Terdapat pengaruh langsung motivasi kerja terhadap kinerja" terbukti. Besarnya pengaruh motivasi kerja terhadap keputusan pembelian sebesar 0.369 hal ini berarti bahwa kinerja dipengaruhi oleh motivasi kerja 3,69\%, sedangkan sisanya sebesar $63,1 \%$ dipengaruhi oleh faktor lain yang tidak termasuk dalam penelitian ini.

Robbins dan Jugde (2008) mendefinisikan motivasi sebagai proses yang menjelaskan intensitas,arah, dan ketekunan seorang individu untuk mencapai tujuanya. Didalam organisasi atau perusahan maka tujuan tersebut adalah tujuantujuan operasional yang mencerminkan minat terhadap perilaku yang berhubungan dengan pekerjaan. Motivasi merupakan hal yang terpenting dalam suatu organisasi guna meningkatkan efektifitas kinerja. Mangkunegara (2002:67) menyebutkan bahwa istilah kinerja berasal dari kata job performance atau actual performance (prestasi kerja atau prestasi sesungguhnya yang dicapai oleh seseorang). Artinya, kinerja adalah catatan tentang hasil-hasil yang diperoleh dari fungsi-fungsi pekerjaan tertentu atau kegiatan tertentu selama kurun waktu tertentu (Ruky,2006:15). 
Hasil penelitian ini mendukung penelitian yang dilakukan oleh Asmirin Noor (2014) yang menunjukkan bahwa motivasi kerja berpengaruh terhadap kinerja pegawai Satuan Kerja Unit Pelaksana Penimbangan (Jembatan Timbang) Dinas Perhubungan dan LLAJ Jawa Timur, yang terlihat dari koefisien jalur positif sebesar 0,389 dengn C.R sebesar 7,232 dan diperoleh probabilitas signifikan yang disyaratkan sebesar 0,05. Artinya motivasi kerja berpengaruh signifikan secara langsung pada kinerja pegawai, yang berarti bahwa jika motivasi kerja meningkat maka akan meningkatkan kinerja pegawai, dan sebaliknya jika motivasi kerja menurun, maka akan menurunkan kinerja pegawai.

\section{Pengaruh Lingkungan Kerja terhadap Kinerja melalui Motivasi sebagai Mediasi}

Dari tabel hasil regresi menunjukkan bahwa nilai koefisien regresi lingkungan kerja terhadap motivasi sebesar 0.343 dengan standar eror 0 , dan nilai signifikansi 0.001. sehingga lingkungan kerja berpengaruh langsung terhadap motivasi demikian juga motivasi signifikan berpengaruh langsung terhadap kinerja. Nilai $\mathrm{M}$ dari Sobel test tidak dapat dihasilkan langsung dari hasil regresi tetapi dengan perhitungan secara manual dengan rumus sobel test. Hasil perhitungan nilai $\mathbf{M}$ dari sobel test sebesar sebesar 1,827, karena nilai yang diperoleh sebesar 1,827 >0,05 maka nilai tersebut membuktikan bahwa motivasi mampu memediasi hubungan pengaruh lingkungan terhadap kinerja.

Lingkungan Kerja merupakan proses penting yana mempengaruhi kinerja kaaryawan termasuk motivasi kerja. Didalam suatu perusahaan hendaknya menjaga lingkungan, sebab kebersihan lingkungan dapat mempengaruhi kesehatan jiwa seseorang. Dapat dibayangkan bila anda bekerja pada suatu tempat yang penuh dengan debu dan bau yang tidak sedap, apalagi pekerja tersebut memerlukan konsentrasi yang cukup tinggi. Dengan adanya lingkungan yang bersih karyawan akan merasa senang sehingga semangat kerja karyawan akan meningkat (Sedarmayanti, 2001:132). Selain itu lingkungan kerja saja tidak cukup apabila tidak adanya motivasi kerja pada karyawan. Karena motivasi merupakan hal yang terpenting bagi perusahaan guna meningkatkan efektivitas kerja karyawan. Dalam hal ini motivasi berperan penting terhadap kinerja apabila karyawan mendapatkan motivasi yang cukup dan positif maka kinerja yang dihasilkan akan baik.

Wood, et.al (2001 :150) motivasi kerja ditentukan oleh keyakinan individu tentang hubungan antara effortperformance dan menyenangi berbagai macam outcome dari level performance yang berbeda-beda. Keith Davis \& Newstroom (1995 : 65) karyawan termotivasi dalam bekerja adalah seseorang yang melihat bahwa pekerjaannya mencapai tujuan-tujuan pentingnya. Wexley and Yukl (1992 : 75), mengemukakan bahwa motivasi kerja adalah sesuatu yang menimbulkan semangat atau dorongan kerja. Oleh sebab itu motivasi kerja biasa disebut pendorong semangat kerja. Inti dari definisi motivasi kerja yang telah dikemukakan di atas menyatakan bahwa motivasi kerja berkaitan erat dengan upaya (effort) yang dikeluarkan seseorang dalam bekerja. Motivasi merupakan faktor penting dalam mencapai kinerja tinggi. Kunci dalam prinsip motivasi menyebutkan bahwa kinerja merupakan fungsi dari kemampuan (ability) dan motivasi. 
Dalam penelitian ini dapat diketahui bahwa peran motivasi kerja memediasi lingkungan kerja dan kinerja berpengaruh positif. Dengan demikian motivasi kerja mampu memediasi lingkungan kerja dan kinerja karyawan pada Rocky Plaza Hotel Padang. Penelitian ini didukung penelitian yang sudah dilakukan oleh Fransisca Olivia Angelina (2017) "Pengaruh Lingkungan Kerja Terhadap Kinerja Karyawan dengan Motivasi sebagai Mediasi pada Wonokoyo Group Surabaya" menyatakan bahwa adanya pengaruh positif motivasi kerja yang memediasi lingkungan kerja dan kinerja karyawan. Hal ini menunjukkan bahwa motivasi kerja memiliki peran penting dalam memediasi lingkungan kerja dan kinerja. oleh karena itu, perusahaan harus mampu memberikan rasa aman dan mampu membuat karyawan lebih berinisiatif untuk menciptakan inovasi-inovasi yang baru sehingga akan membangun kepercayaan diri karyawan dan hal ini cenderung untuk meningkatkan motivasi kerja dan kinerjanya.

\section{KESIMPULAN}

Berdasarkan hasil penelitian tentang Pengaruh Lingkungan Kerja Terhadap Kinerja yang Dimediasi oleh Motivasi Kerja Karayawan Rocky Plaza Hotel Padang maka dapat disimpulkan menjadi beberapa hal sebagai berikut:

1. Terdapat Pengaruh Langsung Lingkungan Kerja Terhadap Kinerja Karyawan Rocky Plaza Hotel Padang. Hal ini dibuktikan dari nilai t hitung sebesar 5.488 dengan nilai signifikansi 0,000 lebih kecil dari $0,05(0,000<0,05)$, dan koefisien regresi mempunyai nilai positif sebesar 0,434. Dapat disimpulkan bahwa lingkungan kerja sangat berpengaruh bagi kelancaran bekerja.

2. Terdapat Pengaruh Langsung Lingkungan Kerja Terhadap Motivasi Kerja Karyawan Rocky Plaza Hotel Padang. Hal ini dibuktikan dari nilai t hitung sebesar 6.663 dengan nilai signifikansi 0,000 lebih kecil dari $0,05(0,000<0,05)$, dan koefisien regresi mempunyai nilai positif sebesar 0,550. Dapat disimpulkan bahwa dengan pemberian motivasi yang lebih baik maka dapat meningkatkan kinerja karyawan Rocky Plaza Hotel Padang. Artinya lingkungan kerja dan motivasi kerja secara bersama-sama memberikan kontribusi dalam meningkatkan kinerja karyawan. Jadi apabila lingkungan kerja dan motivasi meningkat maka kinerja karyawan Rocky Plaza Hotel Padang juga akan meningkat, sebaliknya apabila lingkungan kerja dan motivasi kerja menurun maka kinerja karyawan Rocky Plaza Hotel Padang juga akan menurun.

3. Terdapat Pengaruh Langsung Motivasi Kerja Terhadap Kinerja Karyawan Rocky Plaza Hotel Padang. Hal ini dibuktikan dari nilai t hitung sebesar 5.710 dengan nilai signifikansi 0,000 lebih kecil dari $0,05(0,000<0,05)$, dan koefisien regresi mempunyai nilai positif sebesar 0,547 .

4. Hasil regresi menunjukkan bahwa nilai koefisien regresi lingkungan kerja terhadap motivasi sebesar 0.343 dengan standar eror 0 , dan nilai signifikansi 0.001. sehingga lingkungan kerja berpengaruh langsung terhadap motivasi demikian juga motivasi signifikan berpengaruh langsung terhadap kinerja. Nilai M dari Sobel test tidak dapat dihasilkan langsung dari hasil regresi tetapi dengan perhitungan secara manual dengan rumus sobel test. Hasil perhitungan nilai $\mathbf{M}$ dari sobel test sebesar sebesar 1,827, karena nilai yang diperoleh sebesar 1,827 > 
0,05 maka nilai tersebut membuktikan bahwa motivasi mampu memediasi hubungan pengaruh lingkungan terhadap kinerja.

\section{DAFTAR PUSTAKA}

Aldi, Y., \& Susanti, F. (2019). Pengaruh Stress Kerja Dan Motivasi Kerja Terhadap Prestasi Kerja Karyawan Pada PT. Frisian Flag Indonesia Wilayah Padang. https://doi.org/10.31227/osf.io/et4rn

Arikunto, Suharsimi. 2006 Prosedur Penelitian:suatu Pendekatan Praktik. Cetakan Ketigabelas. Jakarta: PT. Rineka Cipta.

As’ad, Mohammad. 2001. Psikologo Industri. Liberty. Yogyakarta.

Firnidia, Linda. 2008. Pengaruh Motivasi Terhadap Kinerja Pegawai Dinas Pendidikan dan Kebudayaan Kabupaten Jepara. Semarang. Universitas Negeri Semarang.

Ghozali, Imam. 2009. Aplikasi Analisis Multivariate dengan Program SPSS. Semarang: B-P UNDIP.

Gomes, F. Cardosa. 2003. Manajemen Sumber Daya Manusia. Yogyakarta. Andi Offset.

Grifin, R.W. 2003. Manajemen. Jakarta. Erlangga.

Handoko, T.H. 2001. Manajemen Personalia dan Sumber Daya Manusia. Yogyakarta: BPFE Press.

Hasibuan, M. 2003. Organisasi dan Motivasi. Dasar Peningkatan Produktivitas. Jakarta: Bumi Aksara.

Junaidi, R., \& Susanti, F. (2019). Pengaruh Gaya Kepemimpinan Dan Budaya Organisasi Terhadap Kinerja Pegawai Pada UPTD Baltekkomdik Dinas Pendidikan Provinsi Sumatera Barat. https://doi.org/10.31227/osf.io/bzq75

Lubis, A. Y. O., \& Susanti, F. (2019). Pengaruh Gaya Kepemimpinan Dan Kompensasi Terhadap Prestasi Kerja Karyawan (Studi pada PT Japfa Comfeed Indonesia (JCI) Tbk Devisi Fam 1. https://doi.org/10.31227/osf.io/7tbrg

Umar, Husein. 2005. Metode Penelitian untuk Skripsi dan Tesis Bisnis. Edisi Baru. PT. Raja Grafindo Persada. Jakarta.

Mangkunegara, Anwar P. 2006. Evaluasi Kinerja Sumber Daya Manusia. Bandung: PT. Refika Aditama. 
Mathis, Robert L. dan Jackson. John H. 2006. Human Resource Management (Manajemen Sumber Daya Manusia). Edisi 10. Jakarta: Salemba Empat.

Mayliza, R. (2019). Pengaruh Kompensasi Finansial, Lingkungan Kerja Dan Motivasi Kerja Terhadap Kinerja Pegawai Pada Kantor PDAM Kota Payakumbuh. https://doi.org/10.17605/OSF.IO/DZXAF

Mayliza, R. (2019). Pengaruh Gaya Kepemimpinan Dan Disiplin Kerja Terhadap Kinerja Karyawan Dengan Motivasi Kerja Sebagai Variabel Intervening Pada PT. Semen Padang. https://doi.org/10.17605/OSF.IO/FYPQ9.

Mayliza, R. (2019). Kontribusi Sistem Penghargaan Dan Lingkungan Kerja Terhadap Efektifitas Kerja Pegawai Pada Kantor Dinas Pendidikan Kota Padang. https://doi.org/10.17605/OSF.IO/VWZH3

Mayliza, R. (2019). Pengaruh Gaya Kepemimpinan Dan Disiplin Kerja Terhadap Kinerja Pegawai, Dengan Motivasi Kerja Sebagai Variabel Intervening (Studi Pada Dinas Pendidikan Kabupaten Tanah Datar). https://doi.org/10.17605/OSF.IO/JGPDN

Nitisemito, Alex S. 1992. Manajemen Personalia. Jakarta: Ghalia Indonesia. 2000. Manajemen Personalia. Jakarta: Ghalia Indonesia.

Prawirosentono, Suyadi. 1999. Kebijakan Kinerja Karyawan.Yogyakarta:BPF 96

Ridho, M., \& Susanti, F. (2019). Pengaruh Stres Kerja Dan Motivasi Kerja Terhadap Kepuasan Kerja Pada Karyawan Bank Mandiri Syariah Cabang Padang. https://doi.org/10.31227/osf.io/pa2cg

Rivai, veithzal. 2004. Manajemen Sumber Daya Manusia Untuk Perusahaan Dari Teori ke Praktik. Jakarta: PT. Raja Grafindo Persada

Robbins, Stephen, P. 2003. Prinsip-Prinsip Perilaku Organisasi. Jakarta: Erlangga

Sari, Emilia Noviani Asta. 2009. Pengaruh Lingkungan Kerja Terhadap Kinerja Karyawan Bagian Produksi PT. Glory Industrial Semarang II. Semarang. Universitas Negeri Semarang.

Sedarmayanti. 2009. Tata Kerja dan Produktivitas Kerja. Bandung: Mandar Maju.

Siagian, Sondang P. 2003. Manajemen Sumber Daya Manusia. Jakarta: Bumi Aksara. . 2004. Teori Motivasi Dan Aplikasinya. Cetakan Ketiga. Jakarta: Rineka Cipta. 
Simamora, Henry. 1997. Manajemen Sumber Daya Manusia. Yogyakarta: STIE YKPN. Sofyandi dan Garniwa. 2007. Perilaku Organisasional. Edisi Pertama. Graha Ilmu. Yogyakarta.

Sudarmanto. 2009. Kinerja Dan Pengembangan Kompetensi SDM. Cetakan Pertama. Pustaka Pelajar. Yogyakarta.

Sugiyono. 2008. Metode Penelitian Kuantitatif Kualitatif dan R\&D. Bandung: Alfabeta. Wursanto, Ig. 2005. Dasar-Dasar Ilmu organisasi. Yogyakarta. Andi Offset

Susanto, R. (2018). Pengawasan Dan Lingkungan Kerja Terhadap Kinerja Karyawan PT. Bussan Auto Finance. https://doi.org/10.31227/osf.io/m3kge

Widodo, B. H., \& Susanti, F. (2019). Pengaruh Human Relation (Hubungan Antar Manusia), Lingkungan kerja Terhadap Etos Kerja karyawan (Studi Kasus Pada PT. Pelindo Teluk Bayur Padang ). https://doi.org/10.31227/osf.io/dxm8a

Wursanto, Ig. 2005. Dasar-Dasar Ilmu organisasi. Yogyakarta. Andi Offset.

Yudistira, D. S., \& Susanti, F. (2019). Pengaruh Motivasi Kerja Dan Budaya Kerja Terhadap Kinerja Karyawan Dinas Pemberdayaan Masyarakat Dan Desa, Pengendalian Penduduk Dan Keluarga Berencana Kabupaten Pesisir Selatan. https://doi.org/10.31227/osf.io/jk54m 